\title{
THE RELATION BETWEEN GROWTH OPPORTUNITY, LEVERAGE POLICY AND FUNCTION OF COVENANT TO CONTROL THE AGENCY CONFLICT BETWEEN SHAREHOLDERS AND DEBTHOLDERS
}

\author{
Rhini Fatmasari ${ }^{1}$
}

\begin{abstract}
Agency conflict is a phenomenon that relates to the firm's financing policies, especially of those related to the leverage strategies. Some of the former researches revealed the existence of a negative effect between growth opportunity, and either leverage, and debt maturity as one of the efforts in controlling the agency conflict between stockholders and bondholders. By using panel data regression model, this study found that firms with high growth opportunity tend to use low leverage policies with short maturity to control the agency conflict between stockholders and bondholders. On the other hand, firms with low growth opportunity tend to use higher leverage policies with a longer period of debt maturity. Moreover, covenant as a moderating variable, could lower the negative relation between growth opportunity and leverage, but it could not diminish the negative relation between growth opportunity and debt maturity. Debt maturity and covenant also could not be use as substitution variable to lessen the agency conflict.
\end{abstract}

Keywords: growth opportunity, leverage, debt maturity, covenant, stockholders and bondholders conflicts.

JEL Classification: D92, G31

1 The author is a lecturer of study of Economy at PIPS FKIP Universitas Terbuka; rheins2009@gmail.com 


\section{INTRODUCTION}

Modern corporation will still exist and dominate economic life if it has two combinations: assets in place (tangible assets) and investment opportunities (intangible assets). Both combinations can affect the capital structure and the corporate value. In addition, these instruments will also create and exploit the investment opportunities (Arifin: 209). If this investment opportunity is not executed, then the economic activities will be limited to sale and purchase of materials, capital and labor, and already these activities are saturated, highly competitive, and produce only a minimal profit. The current main driver of modern economy is the exploitation of new technologies and the transfer process toward a more capital intensive production. The utilization and execution of investment opportunities can only be done if the company has the adequate financial, technical and human resources.

Concerning the funding issues, companies can obtain them from two sources, first from the company itself, such as the issuance of stock and retained earnings; second from external resources of the company in the form of a debt to a third party, which depends on the funding policy of the company. Regardless the size of the company, usually the company choose to use the fund from outside the company in the form of debt. However, this policy is not without risk. There are certain conditions that can arise from these policies which is the emergence of the so-called agency conflict. In the perspective of agency theory, the conflict between the agent and the principal is caused by an asymmetry of information. Agents who possess information often take more opportunistic actions that benefit themselves. On the other hand, principal with relatively less information demand a higher contribution. The main conflict occurs when the principal received the cash payment in smaller amount. According to Jensen (1986), agency conflict arises when these 2 interests meet in a joint activity, and since this conflict creates a problem (agency cost), then each party will try to reduce it.

In the case of the policy on determining the leverage of the company, the problem that arises is the conflict between shareholders and bondholders. This conflict occurs because of the revenue structure (pay off) and different levels of risk. The revenue structure (pay off) of bondholders earns a fixed income from interest and repayment of the loan, while the shareholders get any excess revenue after the liability that needs to be paid to bondholders. Based on the level of risk, when shareholders through the management exercise a high-risk activity, the level of risk faced by bondholders is much higher than the shareholders (Hanafi, 2005). The level of agency conflict is influenced by the growth opportunities level. Companies with high growth opportunities tend to have higher conflict. This conflict arise when a company deals with investment opportunities on projects with positive NPV that require the use of substantial funds. Under the conditions of low free cash flow and small assets in place, to achieve the funds 
needed to continue the existing projects, the companies tend to take loans. This is the possibility that incite the conflict between shareholders and bondholders.

The agency conflict between bondholders and shareholders can be prevented. There are three mechanisms that offered: the reduction of total debt, short-maturity and covenant. Covenant in Indonesia is known as the trusteeship agreement that must be made by the company at the time of the registration of that company in Indonesia Stock Exchange. The agreement is made between the issuers (companies that issue the bonds) and Trustee (Act No. 8 Th. 1995 on the Capital Market.) The trustees act as a party representing the interests of bondholders as well as providing protection to them.

The description above shows that the agency conflict is a phenomenon that cannot be avoided when a corporation creates debt. The phenomenon that occurred in Indonesia, based on a number of studies, carried out by Nurdin (2001) among others; indicate that the rate of growth companies in the past has a positive and significant relationship with the level of leverage in the present. That means the companies with high growth rates in the past will have a high degree of leverage in the present. In another study, Widyastuti (2007) stated that there are conflicts of interest between managers and shareholders, and between shareholders or managers with creditors in Indonesian companies.

The studies in Indonesia regarding the agency conflict have only revealed the presence or the absence of agency conflicts and the relationship between the investments opportunities and leverage policies that lead agency conflict, but yet none reveal the agency conflict itself. Our current study refers to the study of Nurdin (2001) and Widyastuti (2007) concerning the existence of agency conflict in Indonesia by looking at the growth opportunity variable as one of the variables that influence the conflict, and at the policy leverage as the dependent variable. However, both studies have not seen how to control the agency conflict. This research will enter this area with the variables of growth opportunity, leverage, debt maturity and covenants. Covenant will be used as a moderating variable that affect the relationship between growth opportunities and leverage, and also as moderating variables that influence the relationship between growth opportunities and debt maturity. We also predict the covenant to be an alternative to control the conflict between shareholders and bondholders. Variables that will be developed in this study had previously been used by Blillet et al. (2007) on the case of US. We use growth opportunity to proxy the agency conflict in Indonesia, and we expect it yield new variants among the existing agency conflict studies in Indonesia.

Specifically, this study raises the issue of whether the growth opportunity affects the change of leverage and the debt maturity choice, and whether the effect of growth opportunity 
toward the change of leverage and debt maturity choices would be different if there are covenants as a mechanism to guarantee debts? Explicitly, this study aims to examine the role of covenant to the changes in leverage and debt maturity policies under the condition of different growth level of companies to control the conflict between stockholders and bondholders.

The rest of this paper describes the theory and the third section elaborates the data and methodology used. The results of the estimation model and the analysis are presented in the fourth section, while conclusions and suggestions are given in the last section.

\section{THEORY}

The decision of the funding is based on the selection of funding sources, both internal and external. The choice of the company is influenced by many things, one of which is the investment opportunity. Jensen (1986) states that a company with high investment opportunity usually has a high growth rates, is active in investing, has a low free cash flow and small assets in place. In these conditions, the company tends to use external funds in the form of debt.

On the other hand, the debt policy as a source of corporate funding potentially leads agency conflict between shareholders and bondholders that also will also cause agency costs (Jensen and Mecling, 1976). This condition shows the use of debt, in companies that have a high investment opportunity, will become expensive and cause a high cost of debt. As a result the company will leave a positive NPV projects and lose the opportunities to grow. To avoid the problems on the cost of debt, these companies with high investment opportunity then will choose to use the loan in small amounts, or to use internal funds as an alternative funding. Finally, the relationship between the leverage and investment opportunity will negative.

The above conclusion is also supported by a study of Rajan and Zingales (1995), Johnson (2003) and Billett et al. (2007) Fitriyanti and Hartono (2002) Subekti and Kusuma (2001) which stated that there was a negative relationship between leverage and growth opportunities. Based on empirical evidence, the first hypothesis that will be proposed in this study is: growth opportunity negatively affects leverage changes.

In order to reduce the agency conflicts, companies with high investment opportunity tend to use the debt policy in a small amount and short maturity as one way to reduce investment costs and to increase firm value. Empirical studies such as Johnson (2003), Billett et al., (2007), Barclay and Smith (1995), implies the existence of a negative relationship between growth opportunities and leverage policy. Companies with high growth opportunities tend to use the policy of low leverage and short maturity to reduce the agency conflict and the cost of debt. 
Starting from the empirical evidence mentioned above, the next hypothesis posed is: growth opportunity negatively affects the debt maturity

The negative relationship between growth opportunities and leverage can be lowered down with the inclusion of covenants in the debt issuance as it can reduce the conflict between stockholders and bondholders. Covenant can be used as a guarantee to bondholders that the company will use the existing funds in investments that bring in positive NPV and assurance that the company will prioritize the debt payments to bondholders before making other financial policies in accordance with the agreements stated in the covenant. The use of covenants in reducing the agency conflict between the company and the owners of capital, especially in companies with high growth opportunities, is presented by Smith and Warner (1979). Thus the second hypothesis is: the level of covenants affects the reduction of the negative impact between the growth opportunities and leverage changes.

The selection of different maturity debt at different levels of opportunity growth will also have an impact on the use of covenants. High debt with long maturity tends to use covenant as collateral in the company's debt, while low debt with short maturity does not need to require the covenants in its debt agreements. So the next hypothesis proposed in this study is: the level of covenants affects the reduction of the negative impact between the policy of growth opportunities and the debt maturity.

\section{METHODOLOGY}

\subsection{Data and Variable}

This research was conducted on a publishing event of a covenant. The data required were (1) leverage data of the company, (2) covenant information (agreement of trustee) of the company, (3) debt maturity structure, and (4) growth opportunities and other corporate characteristics data such as firm size, profitability, financially constrained, and fixed assets.

This study uses the company analysis data that issued the bonds accompanied with the issuance of covenant (the trusteeship agreement) from 2003 until 2008. The sample selection is based on purposive sampling with the goal of obtaining a representative sample in accordance with the criteria: non-financial companies that issue bonds during the registration of the company at the Indonesian Stock Exchange.

1. The first variable is the leverage, calculated by formula as follows.

Leverage $=$ Total debt / Total asset

where Total debt = long-term debt + debt in current liabilities. 
2. The second variable is the debt maturity proxied with the maturity of bonds issued by companies listed in the trusteeship agreement and published on the site www.idx.co.id

3. The third variable is the covenant index that measures the covenants contained in the trusteeship agreement. The indexing of covenant refers to the Billet, et al. (2007). But by looking at samples of covenants that exist in Indonesia and their content, this study adjusts some groups of covenants index under the agreement that is used so that the covenant index would be arranged into 24 groups based on its category. The grouping of indicators that compose the covenants can be seen in the following table.

\begin{tabular}{|c|c|c|}
\hline & & $\begin{array}{l}\text { Table } 1 \\
\text { e Indicator of Covenant Index Composition }\end{array}$ \\
\hline No & Type of Covenant & Remarks \\
\hline & & iting the payment to equity holder and the others \\
\hline 2 & $\begin{array}{l}\text { Dividend payment } \\
\text { restriction } \\
\text { Share repurchase } \\
\text { Restrictive }\end{array}$ & $\begin{array}{l}\text { An issue is defined dividend restriction if there is a covenant that restrict the } \\
\text { dividend payment of issuer or subsidiary issuer } \\
\text { An issue is defined repurchase restriction if there is a covenant that restricts the } \\
\text { liberty to do the payment to shareholders and the others. }\end{array}$ \\
\hline & & Limitation to the financial activity \\
\hline 3 & Funded Debt Restrictive & Limiting issuer to issue new debts with 1 year of maturity or more \\
\hline 4 & Subord Debt restrictive & Limiting issuer to issue subordinate, senior and secured debt \\
\hline 5 & Senior debt Restrictive & \\
\hline 6 & Secured Debt Restrictive & \\
\hline 7 & Total Leverage Test & $\begin{array}{l}\text { Included to this category is the limit of accounting variation bases from leverage, } \\
\text { including the minimum requirement of net worth to the minimum requirement } \\
\text { of earning ratio }\end{array}$ \\
\hline 8 & Sale and Lease Back & $\begin{array}{l}\text { This covenant restrict the issuer and its subordinate companies to sell, assure } \\
\text { and lease the assets put as the guaranty to the debt holder without the consent } \\
\text { of the Trustee }\end{array}$ \\
\hline 9 & Stock Issue Restrictive & Limit the issuer to issue common stock or preferred stock \\
\hline & & Investment Policy \\
\hline 10 & Asset Sale Clause & $\begin{array}{l}\text { If issue, or oblige the use of net proceeds from the sale of the majority of the } \\
\text { assets to re-obtain the issue at par or premium par }\end{array}$ \\
\hline 11 & Invest Policy Restrictive & $\begin{array}{l}\text { Restrict the issuer or the subordinate companies to invest or to introduce the } \\
\text { stock share to other party }\end{array}$ \\
\hline 12 & Merger Restrictive & $\begin{array}{l}\text { Limit the issuer or the subordinate companies to do merger, consolidation or } \\
\text { accusation with other companies }\end{array}$ \\
\hline & & Industrial Policy \\
\hline 13 & Assurance & $\begin{array}{l}\text { Forbid issuers or the subordinate companies to give assurance to other party } \\
\text { on their liabilities }\end{array}$ \\
\hline 14 & Business Modification & $\begin{array}{l}\text { Restrict the issuers or subordinate companies to make major changes from } \\
\text { their main industry }\end{array}$ \\
\hline 15 & Capitalization & $\begin{array}{l}\text { Limit the companies to reduce their basic capital and capital paid by the } \\
\text { companies }\end{array}$ \\
\hline
\end{tabular}




\begin{tabular}{|c|c|c|}
\hline No & Type of Covenant & Remarks \\
\hline \multicolumn{3}{|r|}{ Industrial Policy } \\
\hline 16 & Leasing & $\begin{array}{l}\text { Restrict issuers and its subordinate companies to lease/assure their revenue } \\
\text { and issuers capital which is already leased }\end{array}$ \\
\hline 17 & Affiliation & Limit the companies to do transaction with affiliated parties \\
\hline 18 & Loan & $\begin{array}{l}\text { Restrict issuers and its subordinate companies to give loans to other parties, } \\
\text { unless regulated within the trusteeship agreement }\end{array}$ \\
\hline 19 & $\begin{array}{l}\text { Loan to association } \\
\text { company }\end{array}$ & Give loan or credit to association company \\
\hline 20 & $\begin{array}{l}\text { Additional business } \\
\text { activity I }\end{array}$ & To exercise other business activity not mentioned within $A D$ \\
\hline 21 & Bankruptcy & Demand to declare bankruptcy \\
\hline 22 & $\begin{array}{l}\text { Structure of } \\
\text { shareholders }\end{array}$ & Modify the structure of shareholders \\
\hline 23 & $\begin{array}{l}\text { Business control by } \\
\text { other party }\end{array}$ & $\begin{array}{l}\text { Make a management agreement with other party which cause the business } \\
\text { unit to be controlled by other party }\end{array}$ \\
\hline 24 & Share take-over & Take over the shares or assets of the parties \\
\hline
\end{tabular}

Then, the 24 covenant categories are used in the covenant index for each company every year. This variable is given a value $=1$ if the trusteeship agreement has at least one debt instrument, and valued $=0$, if no debt instrument used. Furthermore, the value is summed and divided by 24 to make a covenant index ranges from 0 (for no covenant protection at all) to 1 (for a complete covenant), (Billet et al., 2007).

4. To calculate the growth opportunities, the investment-based proxies with proxy of CAPXBVA are used, which is the comparison between the capital expenditure and the total assets at beginning of year $t$.

$$
C A P X B V A=\frac{\text { Capital Expenditure }}{\text { Total asset }}
$$

CAPXBVA ratio shows that there is a freedom of companies to make new investment opportunities. The company will acquire a greater investment opportunities when investing in their assets compared with the companies that only invest less (Adam and Goyal, 2008).

In this study, control variables are also used, intended to see whether the inclusion of these variables in a model will significantly raise the main independent variable in a way to minimize the error term. Referring to the Billet et.al (2007), there are 3 control variables that can be used, as the following:

1. Fixed assets (Fix), is the ratio of the value of fixed assets listed on financial statements of companies in the year to the book value of total assets, 


$$
\text { Fixed Asset }=\frac{\text { Total Fixed Asset }}{\text { Book Value of Total Asset }}
$$

2. Profitability (profit) is the ratio of EBITDA to book value of total assets,

$$
\text { Profitability }=\frac{\text { EBITDA }}{\text { Book Value of Total Asset }}
$$

3. Firm Size (Size) is the natural logarithm (Ln) of net sales, in millions of dollars.

\section{Financially Constrained}

To determine a company to be categorized as financially constrained and non-financially constrained, the method developed by Moyen (2004), Lang and Ofek (1996), Hovakimian and Titman (2006) and Hidayat (2010) is used.

The classification in this research is done by using the matrix (Table 2). In the first classification, the companies are categorized to be financially constrained and non-financially based on the level of leverage and cash flow. Companies with less leverage than the average debt ratio of the entire sample, categorized as non- financially constrained company, while companies with debt ratios higher than the average debt ratio of the entire sample is then categorized as financially constrained company. Companies that have cash flows greater than the average cash flow of the entire sample is categorized as non-financially constrained, while companies that have cash flow less than the average cash flow of the entire sample are categorized as financially constrained.

\begin{tabular}{l|cc|}
\multicolumn{2}{|c|}{$\begin{array}{c}\text { Table 2. Company Classification : financially constrained } \\
\text { and non financially constrained }\end{array}$} \\
\cline { 1 - 2 } Leverage & High & Low \\
\hline High & $\begin{array}{c}\text { Financial } \\
\text { Constrained } \\
\text { Low }\end{array}$ & \\
\hline
\end{tabular}

Furthermore, companies with high cash flow and high leverage and also low cash flow and low leverage are classified based on the payment of dividend. Companies that pay dividends are categorized as non-financially constrained company, while those that do not pay dividends are categorized as financially constrained company. 


\begin{tabular}{l|r|r|r|r|r|r}
\multicolumn{7}{c}{ Table 3. } \\
\multicolumn{1}{|c|}{ Descriptive Statistic of Employed Variables } \\
\multicolumn{1}{c|}{ Variable } & Range & Minimum & Maximum & Mean & Std. Deviation & Variance \\
\hline Prbh_Leverage & .462871 & -.294715 & .168156 & .00678731 & .099270977 & .010 \\
Profitability & .56779 & -.27553 & .29226 & .0795834 & .09116627 & .008 \\
LN_size & 7.84 & 10.11 & 17.95 & 14.2847 & 1.59090 & 2.531 \\
Debt_mat & 7 & 3 & 10 & 5.30 & 1.854 & 3.439 \\
Fix_asset & .980264 & .019736 & 1.000000 & .48414134 & .265841728 & .071 \\
CAPXBVA & .824561 & -.085593 & .738967 & .13599926 & .196181581 & .038 \\
Covenant_20 & .40 & .15 & .55 & .3920 & .10220 & .010 \\
interaksi_20cov & .36 & -.03 & .33 & .0488 & .07004 & .005 \\
Covenant_24 & .38 & .12 & .50 & .3442 & .08698 & .008 \\
interaksi_24cov & .30 & -.02 & .28 & .0437 & .06161 & .004
\end{tabular}

Note: number of sample $=50$ companies. The raw data and the formation of variable are available with the author and the redactor of BEMP

\subsection{Empirical Model}

Data processing method which applies is a multiple regression on three models developed. The first model, tests the effect of growth opportunities against the change of leverage from the previous year and debt maturity.

$$
\begin{aligned}
& \text { Model 1a. 6Lev }=\alpha_{1}+\beta_{1} \text { CAPXBVA }_{t}+\beta_{2} \text { fix }_{t}+\beta_{3} \text { profit }_{t}+\beta_{4} \text { Ln size }_{t}+\beta_{5} \text { D+ error } \\
& \text { Model 1b. Mat }=\alpha_{2}+\beta_{6} \text { CAPXBVA }_{t}+\beta_{7} \text { fix }_{t}+\beta_{8} \text { profit }_{t}+\beta_{9} \text { Ln size }_{t}+\beta_{10} D+\text { error }
\end{aligned}
$$

The second model, tests the effect of covenants as a relationship moderating variable between the growth opportunities and changes of leverage and the influence of covenant as a relationship moderating variable between growth opportunities and debt maturity.

Model 2a. $\quad 6 \mathrm{LeV}=\alpha_{3}+\beta_{11}$ CAPXBVA $A_{t}+\beta_{12}\left(C A P X B V A_{t}\right.$ x indeks covenant $)+\beta_{13}$ indeks covenant $+\beta_{14}$ profit $_{t}+\beta_{15}$ Ln size $_{t}+\beta_{16} D+$ error.

Model 2b. Mat $=\boldsymbol{\alpha}_{4}+\boldsymbol{\beta}_{17}$ CAPXBVA $_{t}+\boldsymbol{\beta}_{18}$ (CAPXBVA $A_{t}$ indeks covenant $)+\boldsymbol{\beta}_{19}$ fix $t$ $+\beta_{20}$ indeks covenant $+\beta_{21}$ profit $_{t}+\beta_{22}$ Ln Size $_{t}+\beta_{23} D+$ error.

\section{RESULT AND ANALYSIS}

One of the control variables in this study is the Financially Constrained, which is translated into the model in the form of a dummy variable ( 1 for the financially constrained company and 0 for non-financially constrained company). Companies are categorized as financially constrained and non-financially constrained according to the level of leverage, cash flow and dividends. Company classification results that are categorized as financially constrained and non-financially constrained can be seen in table 4, where the number of non-financially constrained and financially constrained companies respectively is 22 and 28. 


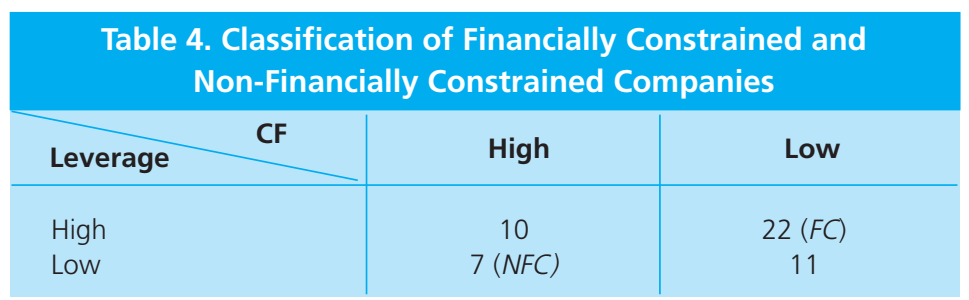

\begin{tabular}{|c|c|c|}
\multicolumn{1}{|c|}{ Category } & $\begin{array}{c}\text { Pay Dividend } \\
(\text { NFC })\end{array}$ & $\begin{array}{c}\text { Pay No Dividend } \\
(F C)\end{array}$ \\
\hline$L(T) C F(T)$ & 6 & 4 \\
$L(R) C F(R)$ & 9 & 2 \\
\hline Total & 22 & 28 \\
\hline
\end{tabular}

In the explanation of hypothesis $1 a$, it is stated that companies with high growth opportunity have smaller leverage changes compared with companies with low growth opportunity. That indicates that leverage of a company with higher growth opportunity will be lower at $t_{0}$ compared with at $t_{-}{ }_{1}$. On the contrary, companies with low growth opportunity have a larger leverage change, which means that leverage on higher than $t_{0}$ at $t_{-}{ }_{1}$ leverage. Statistical tests of hypothesis 1a can be seen in table 5 .

\begin{tabular}{l|r|r}
\multicolumn{2}{c}{ Table 5. } \\
\multicolumn{2}{|c}{ Result test of Hypothesis 1a } \\
\hline Independent Variable & Coefficient & Value t \\
\hline (Constant) & -0.328 & $-2.852 * *$ \\
CAPXBVA & -0.152 & $2.006^{*}$ \\
Fix Asset & 0.023 & 0.412 \\
Profitability & 0.196 & 1.404 \\
Ln Size & 0.023 & $2.943 * *$ \\
Constraint & -0.005 & -0.183 \\
** Significant at the level of $5 \%$ & & \\
* Significant at the level of $10 \%$ & &
\end{tabular}

The test result shows that the $\beta 1$ coefficient investment opportunities proxied with negatively valued CAPXVBA and significant at $\pm 10 \%$. This proves the hypothesis $1 \mathrm{a}$; the growth opportunity negatively affects the change of leverage changes. This implies a high growth opportunity that will cause companies to reduce the amount of its leverage and use more the internal funding sources as an alternative funding. Sources of funding will be utilized to execute the existing investment opportunities. Meanwhile, within the companies with low growth opportunity, the leverage policy would occur otherwise where the use of external funds would 
be greater. This policy is taken to control the agency conflict between shareholders and bondholders.

Furthermore, the hypothesis testing $1 \mathrm{~b}$ concerning the growth opportunity that negatively affects the debt maturity, can be seen in table 6 .

\begin{tabular}{|l|c|c|}
\multicolumn{2}{c|}{$\begin{array}{c}\text { Table 6. } \\
\text { Test Result of Hypothesis 1b }\end{array}$} \\
\hline Independent Variable & Coefficient & Value t \\
\hline (Constant) & -1.759 & -0.786 \\
CAPXBVA & -3.355 & $2.272^{* *}$ \\
Fix Asset & 1.886 & $1.773^{*}$ \\
Profitability & -3.404 & -1.253 \\
Ln Size & 0.472 & $3.078^{* *}$ \\
Constraint & 0.226 & 0.444 \\
\hline
\end{tabular}

The test result shows that the growth opportunity negatively affects the debt maturity, as seen in CAPXVBA coefficient (which is a proxy for growth opportunity), being negative and significant at the level of $10 \%$. This shows that to reduce the conflict between shareholders with bondholders within companies with a high growth opportunity, the short-maturity debt policy is used. While companies with low growth opportunity, tend to make the policies of leverage use with a longer maturity debt.

The third hypothesis tested (Hypothesis 2a) states that the level of covenants affects in the reduction of the negative impacts between the growth opportunity and leverage changes. That means that the interaction between the covenant indexes with CAPXBVA is a variable that may moderate the negative effects between growth opportunity and leverage changes. The test results of hypothesis 2 a can be seen in table 7 .

\begin{tabular}{|c|c|c|c|c|}
\hline \multirow{2}{*}{$\begin{array}{l}\text { Independent } \\
\text { Variable }\end{array}$} & \multicolumn{2}{|c|}{20 covenant indicators } & \multicolumn{2}{|c|}{24 covenant indicators } \\
\hline & Coefficient & Value $\mathbf{t}$ & Coefficient & Value $t$ \\
\hline (Constant) & -0.037 & $2.369 * *$ & -0.037 & $2.369 * *$ \\
\hline$C A P X B V A$ & -0.221 & $3.370 * *$ & -0.221 & $3.370 * *$ \\
\hline (Constant) & 0.391 & $3.461 * *$ & -0.384 & $3.130 * *$ \\
\hline Covindeks*CAPXBVA & 0.306 & $1.694^{*}$ & 0.321 & 1.490 \\
\hline Covenant indeks & 0.111 & 0.950 & 0.025 & 0.180 \\
\hline Profitability & 0.181 & 1.366 & 0.202 & 1.498 \\
\hline Ln Size & 0.023 & $2.934 * *$ & 0.024 & $3.113 * *$ \\
\hline Constraint & -0.006 & -0.241 & -0.005 & -0.186 \\
\hline
\end{tabular}


From table 7 it shows that on 20 covenant indicators, the $\beta_{15}$ CAPXBVA coefficient is positive and significant at $\alpha$ level of $10 \%$. While on the 24 covenants indicators, the $\beta_{15}$ CAPXBVA coefficient is negative and not significant. Based on the above statistical tests, the hypothesis is supported on the 20 indicators of covenant. It proves that there were 20 indicators making up the covenants index contained in the Trusteeship Agreement which also functions as a moderating variable to reduce the negative impact between growth opportunities and leverage changes.

Furthermore, hypothesis $2 \mathrm{~b}$ tests the effect of covenants in reducing the negative impact between the growth opportunities with debt maturity. Statistically, this is the test to see whether the covenant is a moderating variable. The statistical result to prove the hypothesis $2 \mathrm{~b}$ can be seen in table 8.

\begin{tabular}{|c|c|c|c|c|}
\hline \multicolumn{5}{|c|}{$\begin{array}{c}\text { Table } \mathbf{8} \text {. } \\
\text { Test Result of Hypothesis } \mathbf{2 b}\end{array}$} \\
\hline \multirow{2}{*}{$\begin{array}{l}\text { Independent } \\
\text { Variable }\end{array}$} & \multicolumn{2}{|c|}{20 covenant indicators } & \multicolumn{2}{|c|}{24 covenant indicators } \\
\hline & Coefficient & Value $t$ & Coefficient & Value $t$ \\
\hline (Constant) & 5.662 & $18.241 * *$ & 5.662 & $18.241 * *$ \\
\hline CAPXBVA & -2.661 & $-2.033^{*}$ & -2.661 & $-2.033^{*}$ \\
\hline (Constant) & -7.167 & $3.090 * *$ & -6.641 & $-2.700 * *$ \\
\hline Covindeks ${ }^{*}$ CAPXBVA & 1.753 & 0.473 & 1.752 & 0.405 \\
\hline Covenant indeks & -1.117 & -0.463 & -2.563 & 0.936 \\
\hline Profitability & -2.242 & -0.822 & -2.136 & -0.789 \\
\hline Ln Size & 0.519 & $3.299 * *$ & 0.513 & $3.273^{* *}$ \\
\hline Constraint & 0.496 & 0.991 & 0.505 & 1.009 \\
\hline
\end{tabular}

The test result as shown by table 8 implies that is negative and insignificant, both in the test of 20 covenant indicators and 24 covenant indicators. This means that the hypothesis is not supported: covenant is not the moderating variable between growth opportunity and debt maturity. The level of covenant does not influence the reduction of negative impacts between the growth opportunity and debt maturity.

The test result that use covenant as moderating variable between growth opportunity and debt maturity is not statistically proven. This test shows that the presence of covenant does not give the space for companies with high growth to make a loan in longer period. Other implication from this testing also shows that the length of the issued debt maturity or bond maturity, is not directly related with the detailed items within the trusteeship agreement. The observation on debt maturity shows that the policy pattern of bond maturity in Indonesia is not that diverse: ranging from 3 to 10 years. Most of the cases (54\%) are due within 5 years. 
Covenants analyzed in this study are the Trusteeship Agreement, made by issuer and Trustee. The items in the agreement are analyzed to see the indicators which can be used as the basic of the arrangement of covenant index. The preliminary analysis resulted 24 agreement items that served as the indicator of the covenant index arrangement. But not all these covenant index works as moderating variable to reduce the negative relation between growth opportunity and leverage, and between growth opportunity and debt maturity. The existing covenant index then analyzed to obtain the most appropriate indicator. In the final analysis, we obtain 20 indicators in the trusteeship agreement to calculate the covenant index which serves significantly as moderating variable. These indicators are as the following:

a. Covenant that limit the payments to equity holders and others, consist of: Dividend payment restriction, share repurchase restrictive

b. Covenant which provides restrictions on financial activities, which consist of: funded debt restrictive, Senior restrictive debt, total leverage tests, Sale and lease back

c. Covenant related to investment policy, consisting of: Invest policy restrictive, Mergers restrictive,

d. Covenant related to business policy, consisting of Guarantee, Changes in the business, Capital, Collateral, Affiliates, Loan, Restriction on loan or credit to associates, restricted business activities - others than mentioned in $A D$, restriction to declaration of bankruptcy, restriction to change shareholder structure, restriction to create a management agreements with other parties which result in the shift of control of company business by other party, restriction to the takeover of shares or assets of other parties.

Agency conflict is one phenomenon that emerged when a company implements a funding policy which is mainly related with the policy leverage. The conflict here is caused by the conflicts of interest between shareholders to debt holders. Many studies describe the efforts taken by companies to control the agency conflict, one of which is the policy of low leverage and short debt maturity in companies with high growth opportunity. On the other hand, companies with low growth opportunity are to apply high leverage policy with a short maturity debt. In line with the above research, this study also showed a similar thing. But in terms of operational, this research focuses on changes in leverage. In terms of concept, both equally discuss about leverage.

Many other similar studies were conducted on companies with a high growth opportunity that have a small size, low free cash flow and small assets in place. These companies are faced with large investment opportunities but constrained by the limited funding. When a debt policy is taken by the company to overcome the limitations of funding, it will be vulnerable against the emergence of agency conflict between shareholders with debt holder. Finally, to control the agency conflict, companies with high growth opportunity would take the policy of low 
leverage and short debt maturity, or even tend to use the internal resources to execute the existing investment opportunities. This policy of course will result in a lack of funding during the execution of an investment opportunity, which requires substantial funds. This will cause companies with high growth opportunity to lose their investment opportunities and ultimately will lose the opportunity to grow. In the opposite side, companies with low growth opportunity are large-scale companies with a high free cash flow. The high free cash flow caused the conflict between shareholders and managers, since shareholders assume that free cash flow should be distributed as dividends, while managers assume that they have an interest to use it in investment associated with the opportunity to grow. To resolve these conflicts, the companies with low growth opportunity tend to use debt as a source of funding investment in new projects. In other words the leverage policy within the companies with low growth opportunity is one way to control the agency conflict that occurred in the company.

For the companies with high growth opportunity to be able to meet the maximum funding requirements and in the long term to not miss the opportunity to grow, then the other policies that can be taken by the companies to control the agency conflict is to include covenants in their debt issuance. The results showed significant Trusteeship Agreement as the variables that can control the agency conflict. There are 20 items in the trusteeship agreement that significantly serve as variables that can reduce agency conflicts. Hence, in the preparation of the Trusteeship Agreement, these 20 items can be listed.

\section{CONCLUSION}

From the test results of hypothesis, we can make the conclusions as follows:

1. There is a negative effect between growth opportunity and leverage change. Companies with high growth rates tend to use lower leverage and use more their internal funds to finance their growth. This policy is taken as one way to control the agency conflict between shareholders and debt holder and to reduce the cost of debt that eventually will be at risk to their capital structure.

2. The next test shows a negative effect between the growth opportunity and debt maturity. This means that companies with high growth opportunity has a shorter maturity debt than companies with low growth opportunity. Short-maturity debt policy is also one of the alternative solutions for agency conflict between shareholders with bondholders.

3. Covenant proved significantly as a moderating variable that can reduce the negative effects between growth opportunity and leverage. This means that the covenant made between the issuer and the Trustee makes companies with high growth opportunity to make high leverage policies to execute their opportunities to grow. 
Trusteeship Agreement that was made when the company issued their bonds, significantly affects the company's decision to issue a nominally large bond.

4. Covenant, which is predicted to reduce the negative effects from the influence of growth opportunity on the debt maturity, is not proven significantly. The composed Trusteeship Agreement does not allow companies with high growth opportunity to take the longer maturity debt policy. The result of this study is different from the research of Billet et al. (2007) which suggested an increase in the covenants protection on the increase of debt maturity.

5. Covenant Index significantly serves as a moderating variable of 20 indicators. These indicators are not absolute; the number can continue to grow depends on the aspects that can be used as the basis of preparation. In this study, among 24 starter indicators, there were only 20 significant ones that significantly reduce the negative effect between the growth opportunities with the leverage on the Trusteeship Agreement.

It should be underlined that this study has some limitations and can be further expanded for future research development. The first limitation is that this study has constraint in determining the number of samples. This limitation is due to the difficulty of accessing the data of Trusteeship Agreements, since the data is not yet complete in the data center and the number of nonfinancial companies that issue their bonds accompanied by the agreement are relatively much less than the finance company. Second, the number of samples of this study is only 35 nonfinancial companies during the period of 2003 - 2008. The subsequent research suggested adding more sample of financial companies with a more varied proxy approach for a larger amount of data. Third, the proxy employed in this research uses only financial statement data without entering the market price. This is due to few samples which only issue bonds without the issuance of stock share, so it is not possible to obtain its market value. Fourth, this study ignores the functional and role aspects from the Institute of Trustee and the formal juridical aspects. Future studies may include both these aspects within the variable that can reduce agency conflicts in Indonesia. 


\section{REFERENCES}

Adam, Tim and Goyal, K Vidhan (2008), "The Investment Opportunity Set and Its Proxy Variable", the Journal of Financial Research. Vol. XXXI, (1), pp 41-63

Arifin, Zaenal, (2005), "Teori Keuangan dan Pasar Modal", Yogyakarta: Ekonosia.

Barclay, Michael J., and Clifford W. Smith Jr. (1995), "The Maturity Structure of Corporate Debt", Journal of Finance 50, 609-631.

Billett,-et al (2007) "Growth Opportunities and The Choice Of Leverage, Debt Maturity, and Covenants" "The Journal Of Finance Vol. Lxii, No. 2 April 2007

Fitrijanti, Tettet dan Hartono, Jogiyanto (2002), " Set Kesempatan Investasi: Konstruksi Proxy dan Analisis Hubungannya dengan Kebijakan Pendanaan dan Dividen. Jurnal Riset Akuntansi Indonesia Vol. 5, Januari 2002.

Hanafi, Mamduh (2005), Manajemen Keuangan, Jogjakarta: BPFE UGM.

Hidayat, Riskin (2010), Keputusan Investasi dan Financial Constrains: Studi Empiris pada Bursa

Efek Indonesia, Bulletin Ekonomi Moneter dan Perbankan, Volume 12 No.4, April 2010, hal 445-468.

Hovakimian, Gayané and Titman, Sheridan (2006) "Corporate Investment with Financial Constraints: Sensitivity of Investment to Funds from Voluntary Asset Sales", Journal of Money, Credit \& Banking, Mar 2006, Vol. 38 Issue 2, p357-374.

Jensen, Michael C., and William H. Meckling (1976), "Theory of the Firm: Managerial Behavior,

Agency Costs, and Capital Structure", Journal of Financial Economics 3, 305-360.

Johnson, Shane A., (2003) "Debt Maturity and The Effects of Growth Opportunities and Liquidity

Risk on Leverage", Review of Financial Studies 16, 209-236.

Lang, Larry and Ofek, Eli (1996) "Leverage, Investment, and Firm Growth", Journal of Financial Economics, Jan1996, Vol. 40 Issue 1, p3-29, 27.

Moyen, Nathalie (2004) "Investment-Cash Flow Sensitivities: Constrained Versus Unconstrained Firms", Journal Of Finance, Oct 2004, Vol. 59 Issue 5, P2061-2092.

Nurdin (2001) Pengaruh Risiko Bisnis, Profitabilitas, Tingkat Pertumbuhan dan Securable Asset

Terhadap tingkat Leverage Perusahaan, Tesis Program Pasca Sarjana UGM.

Rajan, Raghuram G., and Luigi Zingales (1995), "What Do We Really Know about Capital Structure? Some Evidence from International Data", Journal of Finance 50, 1421-1460. 
Smith Jr. Clifford W., dan Ross L.Watss (1992), "The Investment Opportunity Set and Corporate Financing, Dividend, and Compensation Policies," "Journal of Fianancial Economics, "2:263292

Subekti, Iman dan Kusuma, Wijaya (2001), " Asosiasi antara Kebijakan Pendanaan dan Dividen Perusahaan, serta Implikasinya peda Perubahan Harga Saham" Jurnal Riset Akuntansi Indonesia Vol. 4, Januari 2001.

Widiyastuti, Listiani (2007) "Free Cash Flow Agency Cost, Earning Management dan Mekanisme Kontrol Konflik Keagenan" Tesis Program Pasca Sarjana UGM.

Tim Studi Perwaliamanatan di Pasar Modal Indonesia (2005), "Studi tentang Perwaliamanatan di Pasar Modal Indonesia", Departemen Keuangan RI BAPEPAM: Proyek Peningkatan Efisiensi Pasar Modal. 
324 Bulletin of Monetary, Economics and Banking, January 2011

This page is intentionally left blank 